\title{
Anti-Proliferative Properties, Biocompatibility, and Chemical Composition of Different Extracts of Plantago major Medicinal Plant
}

\author{
Samaneh Rahamouz-Haghighi ${ }^{1}$, Khadijeh Bagheri ${ }^{1}$, Hossein Danafar ${ }^{2}$ and Ali Sharafi ${ }^{2,3^{*}}$ \\ ${ }^{1}$ Department of Plant Production and Genetics, Faculty of Agriculture, University of Zanjan, Zanjan, Iran; ${ }^{2}$ Zanjan \\ Pharmaceutical Biotechnology Research Center, Zanjan University of Medical Sciences, Zanjan; Iran; ${ }^{3}$ Department of \\ Pharmaceutical Biotechnology, School of Pharmacy, Zanjan University of Medical Sciences, Zanjan, Iran
}

Received 18 March 2020; accepted 27 July 2020; published online 20 January 2021

\begin{abstract}
Background: To study the anticancer activity of Plantago major, we assessed the effect of ethanolic, methanolic and acetonic extracts of this plant on HCT-116, SW-480, and HEK-293 cell lines as control. Methods: The cytotoxic activity, biocompatibility, and toxicity were evaluated by MTT assay, hemolysis, and Artemia salina-LD $\mathrm{LD}_{50}$ (on mice) tests, respectively. The analysis of the extracts was performed by GC-MS analysis. Results: The results showed that all the extracts had the most antiproliferative properties on the HCT-116 cell line. The P. major root extract was more effective than the aerial parts, and $\mathrm{IC}_{50}$ values for ethanolic, methanolic and acetonic root extracts were 405.59, 470.16, and $82.26 \mu \mathrm{g} / \mathrm{mL}$, respectively on HCT-116 cell line at $72 \mathrm{~h}$. Hemolysis degree of the ethanolic extract of aerial and root parts were approximately $1 \%$ at $400 \mu \mathrm{g} / \mathrm{mL}$.. Using the ethanolic extracts, the Artemia survived every concentration, and no toxicity was observed. One week after the oral administration of different parts of $P$. major extracts, none of the mice died, even those were administered $2000 \mathrm{mg} / \mathrm{kg}$. The results of $\mathrm{GC} / \mathrm{MS}$ analysis showed that $P$. major extracts contain potential anticancer compounds, such as stearic acid (8.61\%) in aerial parts of methanolic extract and 1,2- Benzenedicarboxylic acid, mono(2-ethylhexyl)ester (88.07\% and $40.63 \%$ ) in aerial and root parts of acetonic extract of $P$. major. Conclusions: Our findings suggest that the $P$. major is a source of potential compounds with antiproliferative properties. DOI: 10.29252/ibj.25.2.106
\end{abstract}

Keywords: Gas chromatography-mass spectrometry, HCT-116 cells, Hemolysis, Lethal dose 50

Corresponding Author: Ali Sharafi

${ }^{2}$ Zanjan Pharmaceutical Biotechnology Research Center, Zanjan University of Medical sciences, Zanjan, Iran; Postal Code: 45139-56184; Tel.: (+98-

24) 33473635; E-mail: alisharafi@zums.ac.ir

\section{INTRODUCTION}

$\mathrm{S}$ ince the most anticancer drugs are associated with severe side effects, new drugs with higher efficacy and fewer adverse effects are needed ${ }^{[1]}$. Natural-based active compounds, such as curcumin, artemisinin, and taxol, have been used for cancer treatment ${ }^{[2]}$. Plant secondary metabolites, owing to their antiproliferative features, have also been utilized as drugs for the treatment of cancer ${ }^{[3]}$.

Plantago major is a medicinal herb from the Plantaginaceae $^{[4]}$. Based on traditional medicine, it has various medicinal uses without significant side effects. Most therapeutic effects of $P$. major described in traditional medicine have not fully been investigated; thus, complementary studies are required to reveal more medicinal characteristics of this plant. Having a broad range of medical application in many countries, $P$. major can be exploited as a source of cost-effective drug candidate $\mathrm{e}^{[5]}$. $P$. major contains important compounds, such as polysaccharides, flavonoids ${ }^{[6,7]}$, phenolic compounds ${ }^{[8]}$, monoterpenoids, and triterpenoids $^{[9]}$, lipids, and caffeic acid derivatives ${ }^{[10]}$. Moreover, caffeoyl phenylethanoid glycosides and iridoids glycosides are the most distinctive category of compounds that show important correspondence in their chemotaxonomy significance ${ }^{[11-13]}$.

Terpenoids are relatively non-toxic substances; these 
compounds have great potential to be applied as chemotherapeutic agents in battling cancer ${ }^{[14]}$. As the main constituents of Plantago extract, triterpenoids have exhibited superb antiproliferative effects and apoptosis on cancer cells ${ }^{[15-17]}$. Fatty acids are one of the most important medicinal sources with multibiological (antimicrobial and antifungal) activities ${ }^{[18]}$.

Till now, various therapeutic effects of $P$. major have been revealed ${ }^{[5]}$. The antibacterial activity of $P$. major has been suggested in Holetz et al.'s study ${ }^{[19]}$. The aquatic extract of $P$. major has been indicated to have an effective antileukemia, anticarcinoma, and antiviral activities, along with modulate cell-mediated immunity ${ }^{[20]}$. Moreover, the aerial parts of this plant have been used for the treatment of anemia and hematopoietic disorders; however, its possessions on hematopoietic cells, mainly on totipotential stem cells, remain unidentified $^{[21]}$. It has been reported that $P$. major L. has an uterotonic action in the guinea pig, a prophylactic influence on mammary cancer in mice, and a protective effect against systemic Streptococcus pneumoniae infection in mice e2-24] $^{[2 .}$. major extract has a significant inhibitive effect on Ehrlich ascites tumor $^{[25]}$.

To the best of our knowledge there is no previous research, associated with the aerial and root parts of $P$. major on colon cancer cells (HCT-116 and SW-480 cell lines). Hence, we aimed to investigate the effect of the whole aerial parts and roots of this plant on two cell lines of colorectal cancer by MTT assay, hemolysis, toxicity activity on Artemia salina and $\mathrm{LD}_{50}$ determination, along with the analysis of the volatile compounds of this plant species.

\section{MATERIALS AND METHODS}

\section{Herbal materials}

The plants were collected from Zanjan city of Iran (geographical coordinates of the collection sites: $\left.36^{\circ} 41^{\prime} 15.5^{\prime \prime} \mathrm{N} 48^{\circ} 24^{\prime} 02.2^{\prime \prime} \mathrm{E}\right)$ and authenticated at the Department of Botany, University of Zanjan, Iran. All the plant sections were cut into small pieces and dried in the shade at room temperature for one week.

\section{Plant extraction}

Approximately 20 grams of the dried aerial (stem and leaf) and root parts of $P$. major was ground to a coarse powder and extracted by the reflux method using $200 \mathrm{~mL}$ of ethanol or methanol for $8 \mathrm{~h}$ and acetone for 3 hours. The extracts were then filtered and concentrated in an evaporator under pressure at $35-45{ }^{\circ} \mathrm{C}$ for $75 \mathrm{~min}$. The extracts were kept at $4{ }^{\circ} \mathrm{C}^{[26]}$.

\section{Cell line culture}

HCT-116, SW-480, and HEK-293 cell lines were obtained from the Pasteur Institute of Iran, Tehran and were cultured in DMEM and RPMI-1640 media supplemented with penicillin-streptomycin (1\%) and $10 \% \mathrm{FBS}$ in $5 \% \mathrm{CO}_{2}$ incubator at $37^{\circ} \mathrm{C}$.

\section{Viability assay}

The inhibitory effect of the ethanolic, methanolic and acetonic extracts of $P$. major on the cell lines was determined by MTT assay. The cells were seeded onto a 96-well plate at a density of $7 \times 10^{3}$ cells/well. The cells were attached and grown for $24 \mathrm{~h}$ to reach 70 $80 \%$ confluency. Subsequently, $10 \mathrm{mg}$ of concentrated extracts was dissolved in $100 \mu \mathrm{L}$ of DMSO and dissolved in $900 \mu \mathrm{L}$ of the culture medium (DMEM or RPMI-1640) for the preparation of 25, 50, 100, 200, and $400 \mu \mathrm{g} / \mathrm{mL}$ of the extracts using dilution method. The extracts were filtered by $0.45-\mu \mathrm{m}$ membrane filters. Medium and DMSO were considered as + and control, respectively. Cells were treated with the prepared extracts and incubated for 1-3 days. Thereafter, $20 \mu \mathrm{L}$ of MTT $(5 \mathrm{mg} / \mathrm{mL})$ was added and kept at an incubator for four hours. The media was then removed by aspiration. DMSO $(200 \mu \mathrm{L})$ was added to each well to dissolve the obtained formazan. The absorbance was read by an ELISA plate reader (Tecan Infinite M200, Austria) at 570 and $690 \mathrm{~nm}$, and the OD was documented ${ }^{[27]}$. The inhibitory rate of the cell growth was considered by: \% Growth inhibition $=(1-\mathrm{OD}$ extract-treated $) / \mathrm{OD}$ negative control $\times 100$

\section{Hemolytic toxicity}

To examine the biocompatibility of the ethanolic extract of aerial and root parts, the hemolysis assay was performed $^{[28]}$. Freshly prepared human RBCs collected in ethylenediaminetetraacetic acid-containing tube were washed with isotonic PBS ( $\mathrm{pH}$ 7.4) by centrifugation at $1663 \times \mathrm{g}$ for $5 \mathrm{~min}$. Next, the tube containing the erythrocytes was resuspended in the same medium at a final hematocrit of $5 \%$. Then aerial and root extracts with the concentration of 25, 50, 100, 200 , and $400 \mu \mathrm{g} / \mathrm{mL}$ were added to $0.4 \mathrm{~mL}$ of diluted human RBC suspension. All of the samples were prepared in triplicate, and the suspension was shaken before incubation at $37{ }^{\circ} \mathrm{C}$ for $4 \mathrm{~h}$. The sample was then centrifuged (Eppendorf Centrifuge 5417R) at $5400 \times \mathrm{g}$ for $5 \mathrm{~min}$ to remove non-lysed human RBCs. Afterwards, $100 \mu \mathrm{L}$ of the supernatant from the sample tube was moved to a 96-well plate. The supernatant was used, and hemoglobin release was assessed at 545 nm. Sodium dodecyl sulfate $(0.1 \%)$ and PBS were used to establish $100 \%$ and $0 \%$ hemolysis as the 
positive and negative samples, respectively. The percentage of hemolysis was described by the following equation where + and - controls are the absorbance of the solution at 100 and $0 \%$ hemolysis. Hemolysis $\%=[($ sample absorbance - negative control)/ (positive control - negative control) $] \times 100$

\section{Toxicity assay on $A$. salina}

The general toxicity of the ethanolic extracts on $A$. salina was assessed ${ }^{[29]}$. A. salina eggs were achieved from Urmia University, the West Azerbaijan Province, Iran. The cysts were seeded in a flask containing $35 \mathrm{~g}$ of $\mathrm{NaCl}$ in $1 \mathrm{~L}$ of distilled water. After incubation for $36-48 \mathrm{~h}$ at $28{ }^{\circ} \mathrm{C}$, the larvae hatched within $48 \mathrm{~h}$. The test was performed on the larvae of brine shrimp $(A$. salina Leach.). At first, a stock solution of $10 \mathrm{mg}$ of ethanolic extract of aerial and root parts was dissolved in $100 \mu \mathrm{L}$ of DMSO and then in $900 \mu \mathrm{L}$ of the medium to prepare the stock $(10 \mathrm{mg} / \mathrm{ml})$. It was diluted to make the concentrations ranging from 0.78125 to $10 \mathrm{mg} / \mathrm{ml}$. Ethanolic extracts $(20 \mu \mathrm{L})$ was added to each well of the 96-well microtiter plates containing $180 \mu \mathrm{L}$ of RPMI-1640 to form the extract concentration ranging from $1000 \mu \mathrm{g} / \mathrm{mL}$ to $7.8125 \mu \mathrm{g} / \mathrm{mL}$. After that, 10 nauplii per well were added to the 96-well plates and incubated at $25{ }^{\circ} \mathrm{C}$ for $24 \mathrm{~h}$. Afterwards, the numbers of surviving nauplii in each well were calculated under a binocular microscope after $24 \mathrm{~h}$. All experimental settings for each concentration were in triplicates. Additionally, the negative control contained only 10 nauplii and artificial sea water. The percentages of nauplii deaths were calculated by considering the number of survivors in the test and control wells. The lethality was determined by Abbott's formula: Lethality $(\%)=[($ Test Control)/Control] $\times 100$.

\section{Oral acute toxicity}

An oral acute toxicity was performed to calculate the $\mathrm{LD}_{50}$. Ten Swiss Albino mice, obtained from the Pasteur Institute of Iran (25-35 g), were selected equally from both sexes. For the adaptation of the mice with laboratory conditions, every five mice were kept in a cage for seven days prior to testing and had free access to food and water according to OECD Guidelines with some modifications ${ }^{[30]}$. Different doses (control, 250, 500, 1000, and $2000 \mathrm{mg} / \mathrm{kg}$ ) of the alcoholic extracts of $P$. major (various parts) were orally administered to each animal. If all animals were survived after $24 \mathrm{~h}$, two additional mice were selected and treated at the highest dose $(2000 \mathrm{mg} / \mathrm{kg})$. If these two mice survived, then the $\mathrm{LD}_{50}$ was more than the limited dose, and the test was stopped. All tested animals were weighed before treatment and $24 \mathrm{~h}$ and one1 week after that.

\section{GC-MS analysis}

GC-MS of the methanolic extracts (due to the better solubility of the compounds in methanol than ethanol) and acetonic extracts of $P$. major aerial and root parts was used for analysis. GC-MS analysis was carried out by Agilent technologies 5975c, USA. Next, $1 \mu \mathrm{L}$ of the methanolic extract was subjected to the GC-MS system equipped with a capillary column $(30 \mathrm{~m} \times 250 \mu \mathrm{m} \times$ $0.25 \mu \mathrm{m}$, Agilent). Helium was used at the flow rate of $1.0 \mathrm{ml} / \mathrm{min}$. The injector and the interface temperature were kept at $350{ }^{\circ} \mathrm{C}$. The column temperature was attuned as follows: the initial temperature was $50{ }^{\circ} \mathrm{C}(2$ min) then increased at a rate of $4{ }^{\circ} \mathrm{C} / \mathrm{min}$ up to $230{ }^{\circ} \mathrm{C}$ (2 min). The identification of the components was determined by comparing mass spectral fragmentation patterns in MS data libraries (NIST08.L) ${ }^{[31]}$.

\section{Statistical analysis}

The experiments were directed in triplicate, and group-wise comparison and statistical analysis of the results were performed by ANOVA and Duncan's new multiple range test. SPSS v21 was used for statistical analyses. $p<0.05$ was considered as statistically significant. The $\mathrm{IC}_{50}$ values were analyzed with ED50plus v1.0 software.

\section{Ethical statement}

The above-mentioned sampling/treatment protocols were approved by the Research Ethics Committee of University of Zanjan, Zanjan, Iran (ethical code: 21699).

\section{RESULTS}

\section{Cytotoxicity activity \\ Cell proliferation inhibition activity of different extracts of the P. major aerial parts}

Based on the results, the alcoholic extracts of $P$. major represented more antiproliferative properties on the HCT-116 in comparison with SW-480 cell line (Fig. 1). Also, the acetonic extract of aerial parts had the most inhibition effect $(59 \%, 43 \%$, and $27 \%$ and $37 \%, 29 \%$, and $23 \%$, respectively) on the viability of HCT-116 cells and normal cell lines at the highest concentration $(400 \mu \mathrm{g} / \mathrm{mL}$ ) in 24,48 , and $72 \mathrm{~h}$, (Fig. 2A, 2B, and 2C).

Despite the lower cytotoxicity of alcoholic and acetonic extracts on SW-480 cells, compared to HCT116 cells, the alcoholic extracts showed 92-94\% viability at the concentration of $400 \mu \mathrm{g} / \mathrm{mL}$ in $24 \mathrm{~h}$, while acetonic extract had no effect at the same time and at 48 and $72 \mathrm{~h}$. Besides, the acetonic extract had the same activity with alcoholic extracts on SW-480 
cells. In both cell lines, the ethanolic extract had a better cytotoxicity effect than methanolic extract (Fig. D-2F and 2G-2I). This proliferation inhibition activity of the cells was not only time-dependent but also dosedependent. The cytotoxic effect of the alcoholic extracts in comparison to acetonic extract on HEK-293 normal cells at $72 \mathrm{~h}$ showed that the alcoholic extracts had low inhibitory effects (between $2 \%$ to13\%) only at the concentrations of 200 and $400 \mu \mathrm{g} / \mathrm{mL}$, whereas the acetonic extract revealed a significant cytotoxicity effect on the HEK-293 cells in all tested concentrations $(25-400 \mu \mathrm{g} / \mathrm{mL})$. Indeed, these results indicated that the alcoholic extracts of aerial parts of $P$. major had significant cytotoxic activity on cancer cell lines, whereas at high concentration, it showed a partial cell proliferation inhibition activity on normal cells. However, the acetonic extract possessed high cytotoxicity activity on both cancer and normal cell lines; therefore, based on the results, the use of acetonic extract is not recommended for the treatment of colorectal cancer.

$\mathrm{IC}_{50}$ values of ethanolic, methanolic and acetonic extracts were calculated as follows: 475.20, 655.09, and $221.64 \mu \mathrm{g} / \mathrm{mL}$ for HCT-116 cells, 646.06, 756.38, and $715.28 \mu \mathrm{g} / \mathrm{mL}$ for SW-480 cells, and 904.98, 1016.55, and $107.85 \mu \mathrm{g} / \mathrm{mL}$ for HEK-293 cell line at $72 \mathrm{~h}$, respectively (Table 1). The lowest $\mathrm{IC}_{50}$ was attributed to the effect of the acetonic extract on HCT116 cells $(221.64 \mu \mathrm{g} / \mathrm{mL})$ and HEK-293 cells (107.85 $\mu \mathrm{g} / \mathrm{mL})$.

\section{Cell proliferation inhibition activity of root part extracts of the $P$. major}

The $P$. major (ethanolic, methanolic and acetonic) root extracts had more cytotoxic activity on the HCT116 than SW-480 cells, similar to the aerial parts extracts (Fig. 3A-3C); however, the $P$. major root extracts had more antiproliferative activity than aerial parts extract on SW-480 cells (Fig. 3D-3F). Although the methanolic extract was found to have less antiproliferative properties than the ethanolic extract of $P$. major root part, the root methanolic extract displayed a more cytotoxic effect on HCT-116 than aerial parts extracts (Fig. 3G-3I). The inhibitory effect of acetonic extracts $P$. major root on the viability of HEK-293 normal cells was considerable (65\%). This effect on root extracts was less than the extracts obtained from aerial parts $(76 \%)$ at $72 \mathrm{~h}$, despite its greater cytotoxic effect on cancer cell lines. $\mathrm{IC}_{50}$ values of ethanolic, methanolic and acetonic extracts were 405, 470, and $82 \mu \mathrm{g} / \mathrm{mL}$ for HCT-116 cells, 513, 687, and $698 \mu \mathrm{g} / \mathrm{mL}$ for SW-480 cells, and 948, 1563, and $125 \mu \mathrm{g} / \mathrm{mL}$ for HEK-293 cells at $72 \mathrm{~h}$, respectively (Table 1). The lowest $\mathrm{IC}_{50}$ was related to the effect of the acetonic extract on HCT-116 cells and HEK-293 cells. Since the $\mathrm{IC}_{50}$ values of the ethanolic extract on HCT-116 and SW-480 cell lines (405 and $513 \mu \mathrm{g} / \mathrm{mL}$ ) were less than a normal cell $(948 \mu \mathrm{g} / \mathrm{mL})$, this extract possessed valuable characteristics. The $\mathrm{IC}_{50}$ values of the alcoholic and acetonic extracts of $P$. major root on cancer cell lines were lower than the aerial parts extracts.
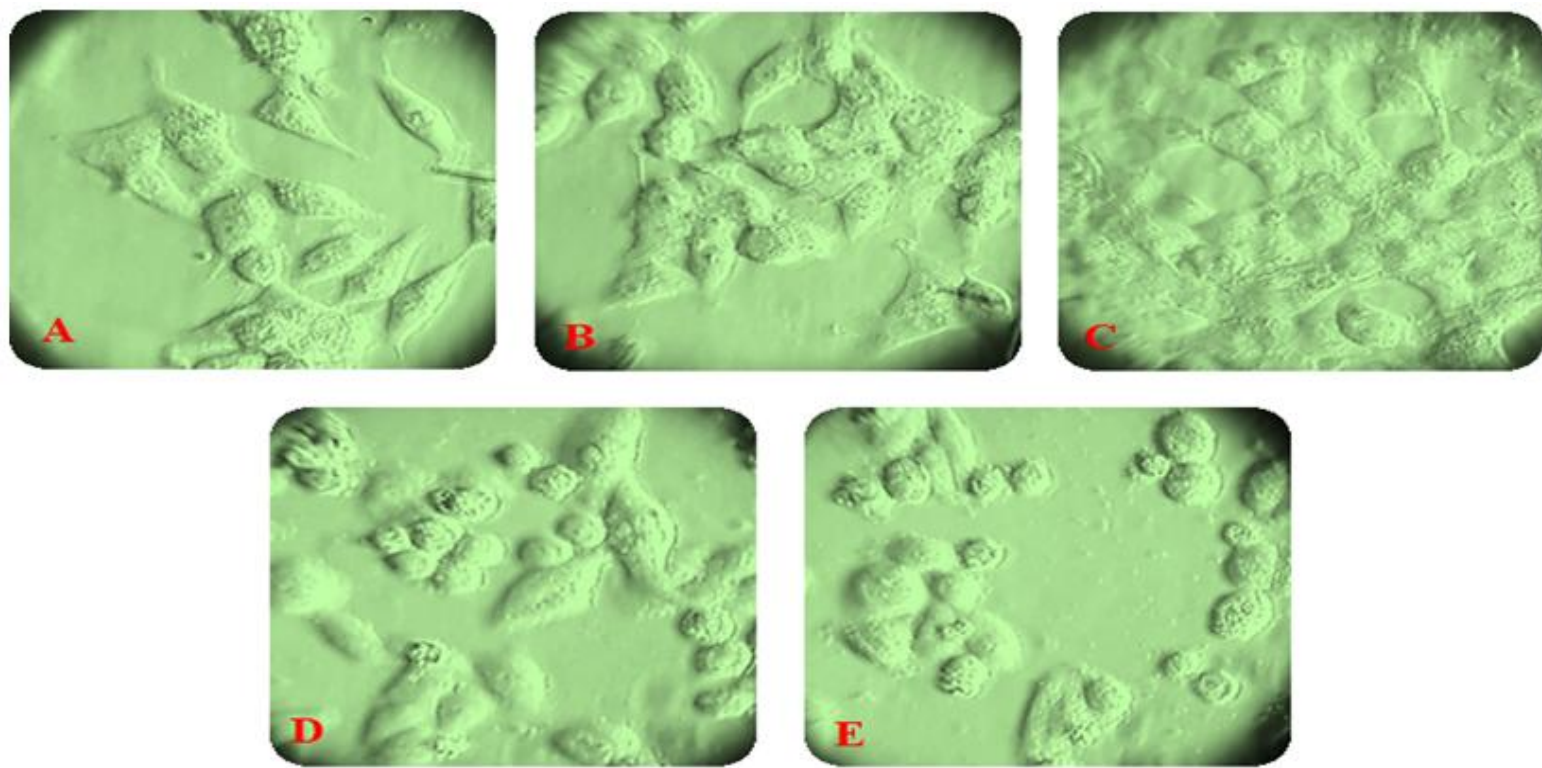

Fig. 1. The growth inhibitory effect of acetonic extract of $P$. major aerial parts on the HCT-116 cancer cell line. (A) Cells were seeded at a density of $7 \times 10^{3}$ cells per well in a 96-well plate. The morphology of cells after treatment with aerial parts acetonic extracts (B) one, (C) two, and (D and E) three days after treatment. 
- HCT 116

(A)

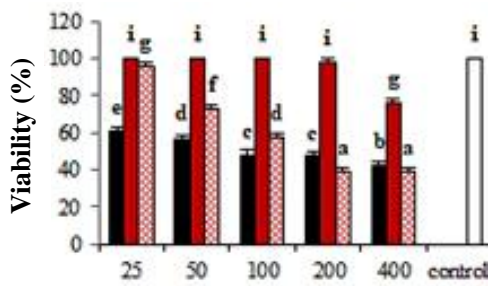

(B)

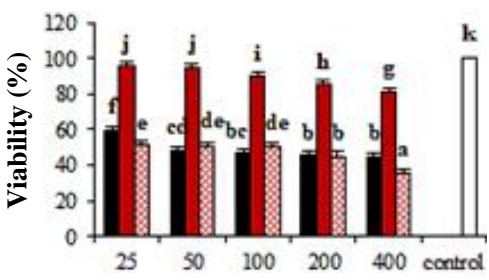

(C)

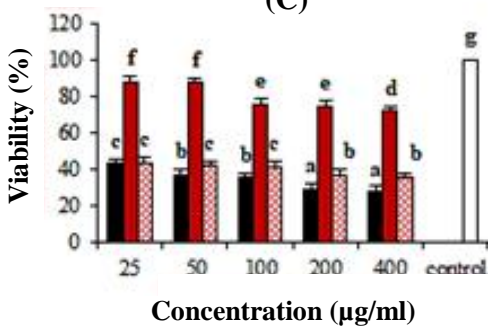

SW 480

(D)

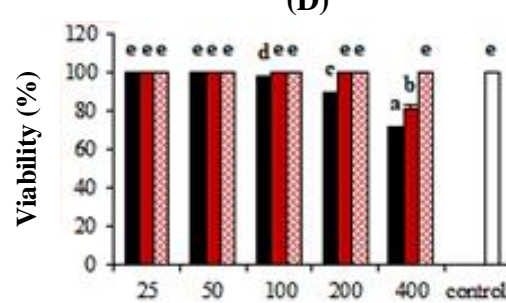

(E)

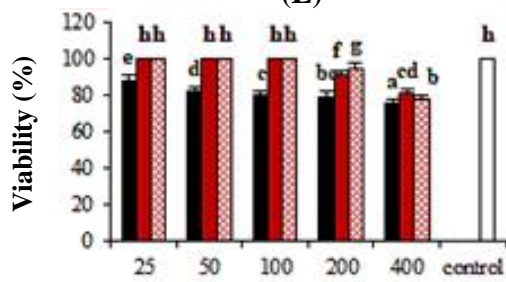

(F)

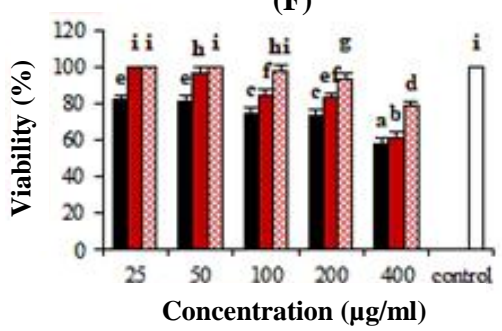

(G)

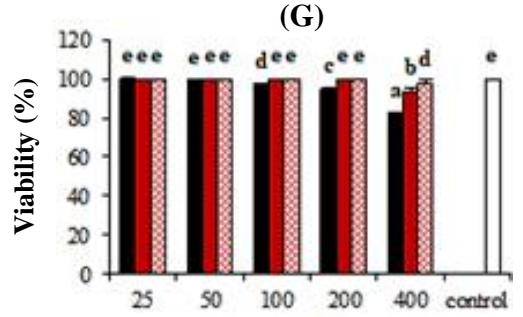

(H)

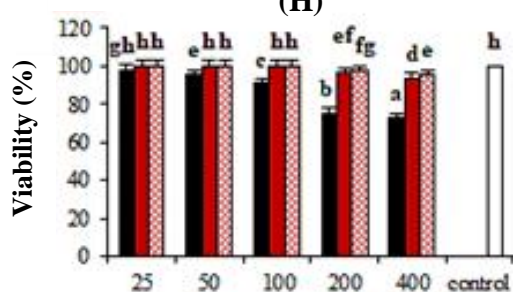

(I)

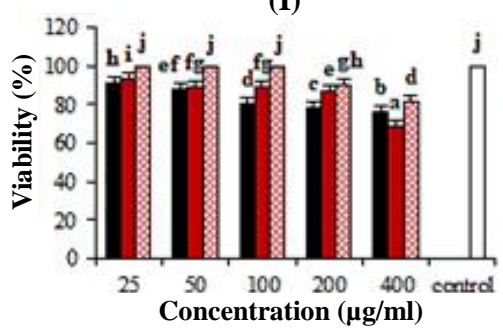

Fig. 2. The result of MTT assay, one, two and three days after treatments. The percentage of the viability of the colorectal carcinoma cell lines (HCT-116 and SW-480) and embryonic kidney normal cell line (HEK-293) were treated with different extracts of aerial parts of $P$. major at 24, 48, and $72 \mathrm{~h}$, respectively. The acetonic (A, B, and C), ethanolic (D, E, and F), and ethanolic (G, H, and I) extracts. Values represent the mean of three replications \pm standard deviation.

The biocompatibility assay of the ethanolic extracts (hemolysis toxicity)

To verify the biocompatibility of the ethanolic extracts of $P$. major aerial and root parts, we examined the hemolytic activity. Hemolysis degree for both the aerial and root parts of $P$. major was determined to be lower than $1 \%$ at the highest concentration (400 $\mu \mathrm{g} / \mathrm{mL}$ ) for $4 \mathrm{~h}$ (Fig. 4).

\section{Toxicity assay of ethanolic extracts on $A$. salina}

The general toxicity of aerial and root parts of $P$. major ethanolic extracts was assessed against $A$. salina. The percentage of lethality was used as a bioassay indicator for the toxicity of ethanolic extracts. At all concentrations of ethanolic extracts ranging from 7.8125 to $1000 \mu \mathrm{g} / \mathrm{mL}$, all of the nauplii were alive, and no toxicity was observed (Fig. 5).

Oral acute toxicity assay of the alcoholic extract $\left(\mathbf{L D}_{\mathbf{5 0}}\right)$

Mice were treated with a range of oral doses. Acute toxicity is known as an in vivo biocompatibility test.
One week after the oral administration of $P$. major aerial and root parts extracts, none of the animals were died. According to OCED and Hodge and Sterner Scale, we can approve that both the aerial and root extracts of $P$. major were practically safe and nontoxic. Furthermore, the change in the body weight is an important factor and an indicator of the potential toxicity (Table 2). The weight of mice after 24 and 168 hours (one week) faintly increased, indicating that all the mice had a natural activity with normal behavior.

\section{Determination of the composition of alcoholic and} acetonic extracts by GC-MS

The composition of different extracts of $P$. major was evaluated by GC-MS, and its components were identified by the NIST08.L library. The extracts of $P$. major showed the presence of fatty acids, phenols, terpenoids, amines, amides, siloxanes, esters, alkanes, aldehydes, benzene derivatives etc. The presence of the volatile components were carried out by GC-MS, which detected acetol (5.03\%), elaidic acid (5.48\%), 
Table 1. IC $_{50}$ estimations of various extracts on HCT-116, SW-80, and HEK-293 cell lines at different exposure times

\begin{tabular}{|c|c|c|c|c|c|c|c|c|c|}
\hline \multirow{2}{*}{ Cell/part } & \multicolumn{3}{|c|}{$24 \mathrm{~h}$} & \multicolumn{3}{|c|}{$48 \mathrm{~h}$} & \multicolumn{3}{|c|}{$72 \mathrm{~h}$} \\
\hline & Methanolic & Ethanolic & Acetonic & Methanolic & Ethanolic & Acetonic & Methanolic & Ethanolic & Acetonic \\
\hline \multicolumn{10}{|l|}{ НСТ-116 } \\
\hline Aerial & $1391.12 \pm 3.1$ & $930.87 \pm 2.3$ & $436.76 \pm 2.5$ & $1170.76 \pm 1.8$ & $698.60 \pm 3.1$ & $307.34 \pm 4.5$ & $655.09 \pm 1.9$ & $475.20 \pm 3.0$ & $221.64 \pm 2.2$ \\
\hline \multicolumn{10}{|l|}{ SW-480 } \\
\hline Aerial & $4065.77 \pm 2.3$ & $2877.36 \pm 2.4$ & $3876.00 \pm 4.8$ & $2822.86 \pm 2.2$ & $990.24 \pm 3.0$ & $1355.71 \pm 3.4$ & $756.38 \pm 2.6$ & $646.06 \pm 3.5$ & $715.283 \pm 3.4$ \\
\hline \multicolumn{10}{|l|}{ HEK-293 } \\
\hline Aerial & $3877.36 \pm 9.2$ & $3353.17 \pm 2.3$ & $204.70 \pm 3.7$ & $2366.70 \pm 4.1$ & $2381.27 \pm 1.4$ & $107.82 \pm 2.5$ & $1016.55 \pm 3.8$ & $904.98 \pm 2.6$ & $107.85 \pm 2.7$ \\
\hline Root & $8824.49 \pm 3.6$ & $4026.77 \pm 5.8$ & $246.42 \pm 1.9$ & $4202.72 \pm 4.2$ & $1443.96 \pm 2.4$ & $184.76 \pm 4.3$ & $1563.04 \pm 1.3$ & $948.15 \pm 3.9$ & $125.89 \pm 1.5$ \\
\hline
\end{tabular}

$\mathrm{ED}_{50}$ plus V1.0 gives an estimated value of $\mathrm{IC}_{50}$; Mean of three replications $\pm \mathrm{SD}$ at 24, 48, and $72 \mathrm{~h}$. 


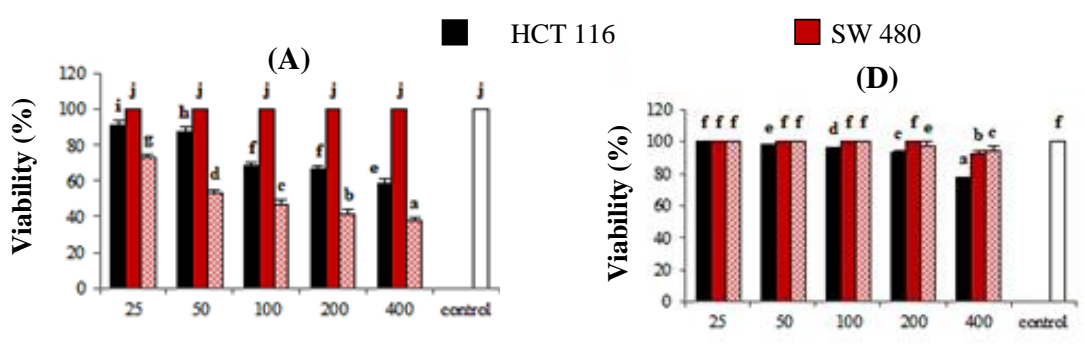

(B)

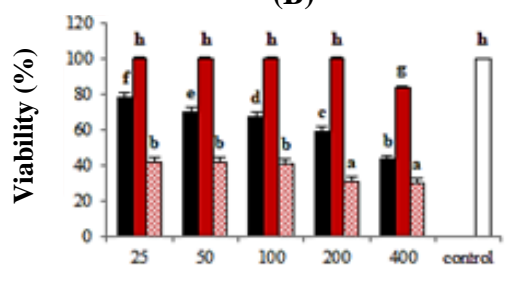

(C)

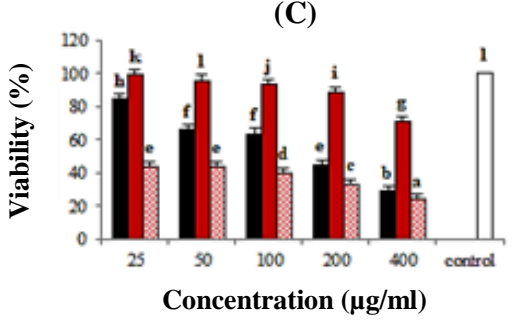

(E)

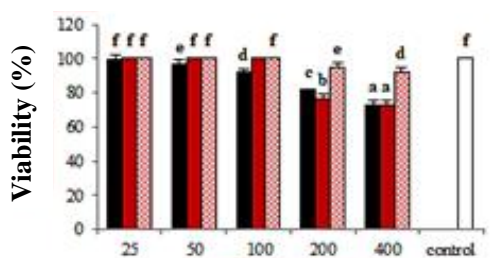

(F)

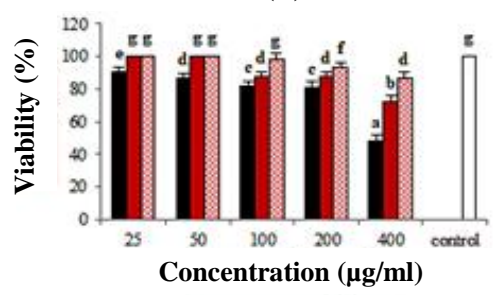

区 HEK 293

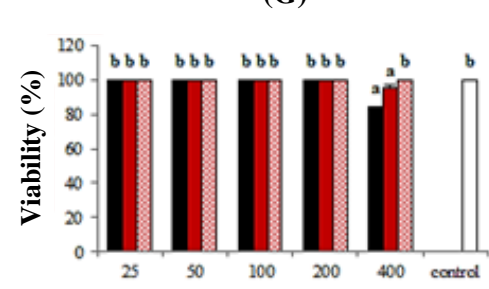

(H)

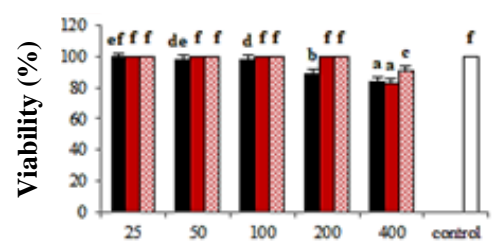

(I)

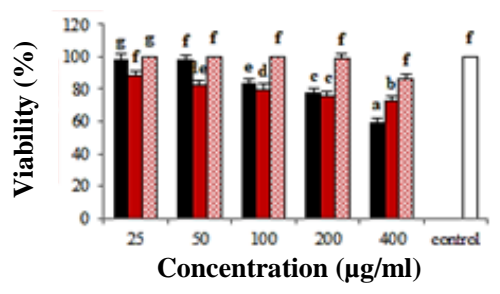

Fig. 3. The result of MTT assay, one, two and three days after treatments. The percent of the viability of the colorectal carcinoma cell lines (HCT-116 and SW-480) and embryonic kidney normal cell line (HEK-293) were treated with different extracts of the root part of $P$. major at 24, 48, and 72 h, respectively. The acetonic (A, B, and C), ethanolic (D, E, and F), and methanolic (G, H, I) extracts. Values represent the mean of three replications \pm standard deviation.

octacosane (6.12\%), octadecanoic acid (8.61\%), and palmitic acid (15.18\%) compounds in the analysis of the methanolic extract of the $P$. major aerial part. However, in the acetonic extracts, it found $\operatorname{Bis}(2-$ ethylhexyl) phthalate (3.67\%), 1,2-Benzenedicarboxylic acid, and mono(2-ethylhexyl) ester $(88.07 \%)$. GC-MS also detected octasiloxane, $1,1,3,3,5,5,7,7,9,9,11,11,13,13,15,15$-hexadecamethyl(4.97\%), cyclohexasiloxane, dodecamethyl- (6.35\%), verbenone $(6.96 \%), \quad$ isoborneol $(8.68 \%)$, tetradecamethylcycloheptasiloxane $(9.74 \%)$, and $\mathrm{n}$ hexadecanoic acid (13.8\%) in the methanolic extract of P. major root part and heneicosane $(5.23 \%)$, cis-9hexadecenoic acid (7.99\%), n-hexadecanoic acid (9.88\%), 13-Docosen-1-ol, (Z)- (15.91\%) 1,2benzenedicarboxylic acid, and mono(2-ethylhexyl) ester $(40.63 \%)$ in the acetonic extracts (as the dominant constituents). A list of compounds identified by GC-MS analysis is represented in Supplementary Table 3. In the present study, the common compounds in the methanolic extracts of both parts of the plant were benzaldehyde, 2-nitro,diaminomethylidenhydrazone $(0.25 \%$ and $1.40 \%)$, pentadecanoic acid, 13-methyl-,methyl ester $(0.36 \%$ and $1.76 \%)$, hexadecamethylcyclo-octasiloxane $(0.32 \%$ and $4.51 \%)$, and hexadecanoic acid $(15.17 \%$ and $13.79 \%$ ); however, in the acetonic extracts, the most frequent compounds were 1,2-benzenedicarboxylic acid, mono(2-ethylhexyl) ester $(88.07 \%$ and 40.63\%), 2-pentanone, 4-hydroxy-4-methyl$(0.12 \%$, and $1.29 \%)$, and Oxirane,heptadecyl- (1.01\% and $1.98 \%$ ), respectively. Both cyclohexasiloxane

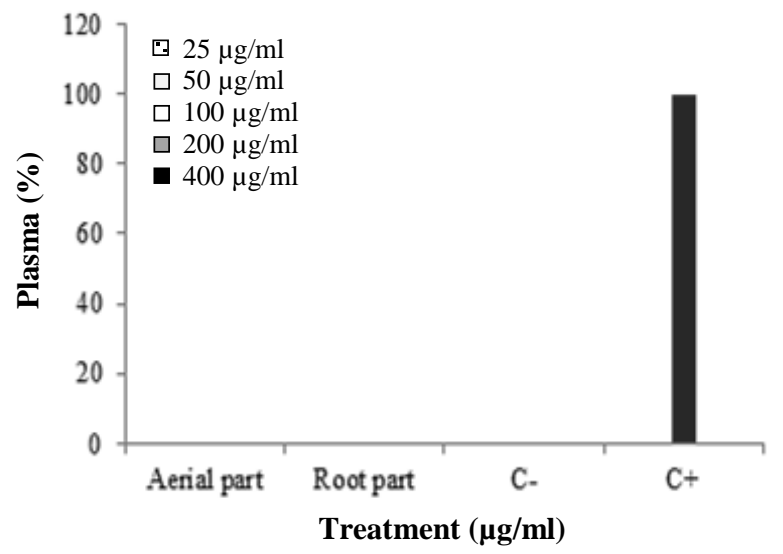

Fig. 4. Hemolytic assay to verify the biocompatibility of ethanolic extracts of $P$. major aerial and root parts. 
dodecamethyl-/CAS number: 540-97-6 (1.71\%, 6.35\%, $0.89 \%$, and $0.47 \%$ ) and cycloheptasiloxane, tetradecamethyl-/CAS number: 107-50-6 (1.16\%, 9.74\%, $1.02 \%$, and $1.68 \%$ ) compounds were cyclic methyl siloxanes and found in both the methanolic and acetonic extracts of aerial and root parts of the plant with different percentage, respectively.

\section{DISCUSSION}

$P$. major is a medicinal plant with various therapeutic benefits. P. major extract can inhibit the cell proliferation of melanoma, renal and mammae ${ }^{[32]}$, skin $^{[10]}$, leukemia ${ }^{[33]}$, breast adenocarcinoma, and melanoma (UACC-62) cell lines ${ }^{[16]}$. The in vitro cytotoxic activity of the methanolic extract of $P$. major has been evaluated on HCT-15, SQC-UISO, OVCAR, and $\mathrm{KB}^{[21]}$, which demonstrated that $P$. major has hematopoietic activity. A comprehensive literature review on $P$. major extract, as an antineoplastic agent, revealed that this plant is an efficient chemoprophylactic and antimetastatic agent against several malignancies, such as breast cancer, hepatoma, and Ehrlich ascites tumor ${ }^{[23,34-36]}$. Based on the research conducted in 2013, P. major extract displayed a proapoptotic impact on the hypergastrinemia rat (Rattus norvegicus) model. This effect has been attributed to the increased level of caspase $3^{[37]}$. Cytotoxicity potential of methanolic extracts from leaves of $P$. major were evaluated against three human cancer cell lines. The results indicated that $P$. major extracts have cell proliferation inhibition activity on breast adenocarcinoma and melanoma cell lines recommended by the National Cancer Institute (USA) ${ }^{[16]}$.

Considering the aforementioned properties of $P$. major, in the first phase of the current study, the cytotoxic effects of the different extracts of $P$. major was examined by MTT test on HCT-116, SW-480, and HEK-293. The ethanolic, methanolic and acetonic extracts of $P$. major exhibited a significant cytotoxic activity on colorectal carcinoma cell lines. Based on the obtained results, the ethanolic extract was more cytotoxic compared to the methanolic extract and did not show any significant cytotoxicity effect on the normal cell line, except for in the concentrations of 200 and $400 \mu \mathrm{g} / \mathrm{mL}$. In this regard, the alcoholic extracts derived from the root parts of $P$. major might be deliberated as a valuable source of metabolites with potential uses as antitumor drug precursors. The US National Cancer Institute argues that the $\mathrm{IC}_{50}$ value should be below $30 \mu \mathrm{g} / \mathrm{mL}$ so that a crude extract can serve as an appropriate agent for further refinement ${ }^{[2]}$. The root extracts of $P$. major showed more cytotoxicity than the aerial parts (leaf and stem) extracts and had a lower and more valuable $\mathrm{IC}_{50}$ index at $72 \mathrm{~h}$. Indeed, these results indicated that the alcoholic extracts of aerial parts of $P$. major had significant cytotoxic activity on cancer cell lines, whereas at high concentration, it showed a partial cell proliferation inhibition activity on normal cells. However, the acetonic extract possessed high cytotoxicity activity on both cancer and normal cell lines; therefore, using acetonic extract is not recommended for the treatment of colorectal cancer. Since the $\mathrm{IC}_{50}$ value of the ethanolic extract on HCT-116 and SW-480 cell lines (475.20 and $646.06 \mu \mathrm{g} / \mathrm{mL}$ ) was less than a normal cell $(904.98 \mu \mathrm{g} / \mathrm{mL})$; hence, it can be considered as valuable and useful extracts for medicinal treatment.

In the second phase of the current study, aerial and root parts of $P$. major extracts were evaluated by hemolysis assay, general toxicity assay on A. salina and oral acute toxicity study $\left(\mathrm{LD}_{50}\right)$ on adult Swiss Albino mice. The study of Atta et al. ${ }^{[38]}$ has reported

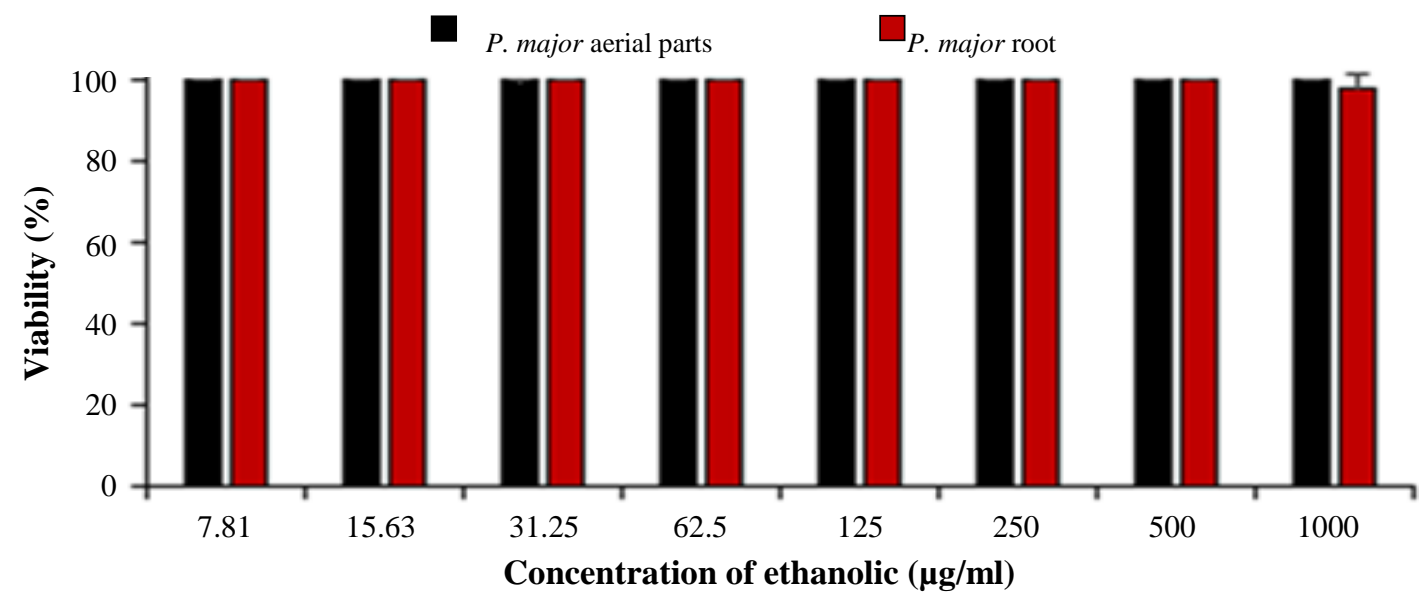

Fig. 5. Toxicity of ethanolic extracts of P. major on A. salina 
Table 2. Weight change and Mortality rates of mice after 24 hours and one week, submitted to various doses of P. major

\begin{tabular}{cccccc}
\hline Groups & $\begin{array}{c}\text { Dose } \\
(\mathbf{m g} / \mathbf{k g})\end{array}$ & $\begin{array}{c}\text { No. of } \\
\text { animals }\end{array}$ & $\begin{array}{c}\text { Mean weight of } \\
\text { animals } \mathbf{( 2 4} \text { h) }\end{array}$ & $\begin{array}{c}\text { Duration of study } \\
\text { (one week) }\end{array}$ & $\begin{array}{c}\text { Dead rate } \\
(\mathbf{\%})\end{array}$ \\
\hline Control & - & 5 & $30 \pm 1.19$ & $34 \pm 1.11$ & $\mathbf{0}$ \\
& 175 & 5 & $35 \pm 1.10$ & $36 \pm 1.27$ & 0 \\
M. A. M & 1750 & 5 & $38 \pm 1.27$ & $37 \pm 1.58$ & 0 \\
& 5000 & 5 & $29 \pm 1.58$ & $31 \pm 1.30$ & 0 \\
& 17.5 & 5 & $30 \pm 1.21$ & $31 \pm 1.27$ & 0 \\
M. A. E & 175 & 5 & $35 \pm 1.64$ & $34 \pm 1.15$ & 0 \\
& 1750 & 5 & $39 \pm 2.23$ & $38 \pm 1.45$ & 0 \\
& 5000 & 5 & $25 \pm 0.70$ & $28 \pm 1.33$ & 0 \\
M. R.M & 17.5 & 5 & $33 \pm 2.05$ & $33 \pm 1.58$ & 0 \\
& 175 & 5 & $35 \pm 1.42$ & $37 \pm 1.58$ & 0 \\
& 1750 & 5 & $39 \pm 2.23$ & $39 \pm 1.76$ & 0 \\
& 5000 & 5 & $25 \pm 1.45$ & $26 \pm 0.79$ & 0 \\
M. R. E & 17.5 & 5 & $35 \pm 1.33$ & $34 \pm 2.57$ & 0 \\
& 175 & 5 & $36 \pm 2.91$ & $37 \pm 0.79$ & 0 \\
\hline
\end{tabular}

Value is mean \pm standard deviation. M.A.M and M.A.E., $P$. major aerial parts methanolic and ethanolic extracts, respectively; M.R.M. and M.R. E., P. major root methanolic and ethanolic extracts, respectively.

that the oral administration of $P$. major seed methanol extracts in doses up to $2.5 \mathrm{~g} / \mathrm{kg}$ body weight did not cause any major signs of acute toxicity, and no deaths were reported up to $72 \mathrm{~h}$ after the oral $\operatorname{administration}^{[38]}$. In this study, at all the concentrations of extracts, we observed no toxicity. Hence, it confirms the safety of these extracts and shows that these extracts are practically nontoxic. Mirzaei et al. ${ }^{[39]}$ selected the $P$. major to investigate its toxicity against both $A$. salina and $A$. uramiana. The result showed a positive correlation between the data obtained from the two aforesaid species, and the $\mathrm{LC}_{50}$ of the $P$. major was $303.7 \mu \mathrm{g} / \mathrm{ml}$ for the methanolic extract, whereas the thymol standard possessed the $\mathrm{LC}_{50}$ value of $7.2 \mu \mathrm{g} / \mathrm{ml}$.

Indeed, it can be concluded that this extract did not exhibit high toxicity in comparison with the thymol. Thus, this medicinal plant can be considered as a safe and non-toxic agent ${ }^{[39]}$. This result showed that the high concentration of both aerial and root parts of $P$. major did not affect the membrane integrity of RBCs and both $P$. major aerial and root extracts are biocompatible.It is interesting to note that the hemolytic activity of $P$. major has not been reported so far, and the obtained data indicated that this medicinal plant is practically nonhemolytic since its hemolysis value is below $1 \%$. It also been reported that when the hemolysis percentage does not exceed $10 \%$, it can serve as a non-toxic agent ${ }^{[40]}$. Moreover, we performed GC-MS to investigate the components of the extracts of aerial and root parts of $P$. major. The GC-MS analysis of extracts from $P$. major revealed the existence of fatty acids, terpenoids, siloxanes, and other medicinal compounds. Therefore, the extracts can be used as anticancer drugs against tumor growth and propagation because $P$. major has effective anticancer compounds. Some of the compounds identified in our study of analysis of the $P$. major extracts include Silanediol, dimethyl- ${ }^{[41]}$, camphor $^{[42]}$, Borneol ${ }^{[43]}$, Isoborneol/Isocamphol $^{[44]}$, 1,2-Benzenedicarboxylic acid, and mono(2-ethylhexyl) ester with antiviral features $^{[45]}$. Two antimalarial compounds, i.e. 2,4-Ditert-butylphenol $^{[46]}$ and n-hexadecanoic acid ${ }^{[47]}$, were also found in the root extracts. Nortriptyline is a commercially available compound that has antidepressant properties ${ }^{[48]}$; however, most of the compounds reported in the extracts have antibacterial, antifungal, anticancer, antioxidant and antiinflammatory properties and are fatty acid. Fatty acids, such as oleic acid, linoleic acid, and palmitic acid, are important sources with antimicrobial and antifungal activities $^{[18]}$. The antimicrobial properties of $P$. major are attributed to the presence of camphor, bornyl acetate, and borneol compounds; the biological activities of these compounds have previously been investigated $^{[49]}$.

Our findings support the notion that the extracts of $P$. major might contain a variety of secondary metabolites that represent the multi-biological activities, which can be applied for the development of antitumor drug 
precursors. The purification of these bioactive compounds is thought to be useful for the formulation of therapeutic agents against cancer. Some of the compounds identified in this study, including, 2,4-Ditert-butylphenol, camphor, gentisic acid, isoborneol, leinoleic acid, methyl ester/linoleic acid ester, myristic acid, methyl sterate, oleic acid, palmitic acid, pcymene, stearophanic acid, trans-anethole etc., are therapeutically important.

\section{ACKNOWLEDGEMENTS}

The study was financially supported by University of Zanjan, Zanjan, Iran. The authors would like to thank the authority of Department of Pharmaceutical Biotechnology, School of Pharmacy, Zanjan University of Medical Sciences, Zanjan, Iran for providing laboratory equipment.

CONFLICT OF INTEREST. None declared.

\section{REFERENCES}

1. Powis G. Dose-dependent metabolism, therapeutic effect, and toxicity of anticancer drugs in man. Drug metabolism reviews 1983; 14(6): 1145-1163.

2. Rajkumar V, Gunjan G, Ashok Kumar R, Lazar M. Evaluation of cytotoxic potential of Acorus calamus rhizome. Ethnobotanical leaflets 2009; 7: Article 2.

3. Gali-Muhtasib H, Bakkar N. Modulating cell cycle: current applications and prospects for future drug development. Current cancer drug targets 2002; 2(4): 309-336.

4. Wang H, Zhao C, Huang Y, Wang F, Li Y. Chemical constituents and bioactivities of plantaginis herba. Hong Kong medicinal journal 2015; 22: 29-35.

5. Najafian Y, Hamedi SS, Farshchi MK, Feyzabadi Z. Plantago major in traditional persian medicine and modern phytotherapy: a narrative review. Electronic physician 2018; 10(2): 6390-6399.

6. Radu N, Ghita I, Coman O, Rau I. Therapeutic effect of flavonoids derived from Plantago species. Molecular crystals and liquid crystals 2010; 523(1): 273-281.

7. Radu N, Ghita I, Rau I. Therapeutic effect of polysaccharides from Plantago species. molecular crystals liquid crystals 2010; 523(1): 236-246.

8. Dalar A, Türker M, Konczak I. Antioxidant capacity and phenolic constituents of Malva neglecta Wallr. and Plantago lanceolata L. from Eastern Anatolia Region of Turkey. Journal of herbal medicine 2012; 2: 42-51.

9. Afifi M, Salama O, Hassan M, Naeim Z, Mohammed K. Phenolic constituents of Plantago albicans L. Journal of pharmaceutical sciences 2000; 16(2): 204-212.

10. Samuelsen AB. The traditional uses, chemical constituents and biological activities of Plantago major L. A review. Journal of ethnopharmacology 2000; 71(1-
2): $1-21$.

11. Rønsted N, Göbel E, Franzyk H, Jensen SR, Olsen CE. Chemotaxonomy of Plantago. Iridoid glucosides and caffeoyl phenylethanoid glycosides. Phytochemistry 2000; 55(4): 337-348.

12. Taskova R, Evstatieva L, Handjieva N, Popov S. Iridoid patterns of genus Plantago L. and their systematic significance. Zeitschrift für naturforschung C. 2002; 57(1-2): 42-50.

13. Janković T, Menković N, Zdunić G, Beara I, Balog K, et al. Quantitative determination of aucubin in seven Plantago species using HPLC, HPTLC, and LC-ESIMS methods. Analytical letters 2010; 43(16): 24872495.

14. Akihisa T, Yasukawa K, Tokuda H. Potentially cancer chemopreventive and anti-inflammatory terpenoids from natural sources. Studies in natural products chemistry 2003; 29: 73-126.

15. Hertog MG, Hollman PC, Katan MB, Kromhout D. Intake of potentially anticarcinogenic flavonoids and their determinants in adults in The Netherlands. Nutrition and cancer 1993; 20: 21-29.

16. Gálvez M, Martín-Cordero C, López-Lazaro M, Cortés F, Ayuso MJ. Cytotoxic effect of Plantago spp. on cancer cell lines. Journal of ethnopharmacology 2003; 88(2-3): 125-130.

17. Sugiyarto AD, Dwisetyawani A, Pitoyo A. Estimasi kemelim pahan dan distribusi Plantago major L. di Gunung Lawu. Biodiversitas 2006; 7(2): 143-146.

18. Krishnaveni M, Dhanalakshmi R, Nandhini N. GC-MS analysis of phytochemicals, fatty acid profile, antimicrobial activity of Gossypium seeds. International journal of pharmaceutical sciences review and research 2014; 27(1): 273-276.

19. Holetz FB, Pessini GL, Sanches NR, Cortez DAG, Nakamura CV, Dias Filho BP. Screening of some plants used in the Brazilian folk medicine for the treatment of infectious diseases. Memórias do Instituto Oswaldo Cruz 2002; 97(7): 1027-1031.

20. Chiang LC, Chiang W, Chang MY, Lin CC. In vitro cytotoxic, antiviral and immunomodulatory effects of Plantago major and Plantago asiatica. American journal chinese medicine 2003; 31(2): 225-234.

21. Velasco-Lezama R, Tapia-Aguilar R, Román-Ramos R, Vega-Avila E, Pérez-Gutiérrez MS. Effect of Plantago major on cell proliferation in vitro. Journal of ethnopharmacology 2006; 103(1): 36-42.

22. Shipochliev T. Uterotonic action of extracts from a group of medicinal plants. Veterinarno meditsinski nauki 1981; 18(4): 94-98.

23. Lithander A. Intracellular fluid of waybread (Plantago major) as a prophylactic for mammary cancer in mice. Tumor biology 1992; 13(3): 138-141.

24. Hetland G, Samuelsen AB, Løvik M, Paulsen BS, Aaberge IS, Groeng EC, Michaelsen TE. Protective effect of Plantago major L. Pectin polysaccharide against systemic Streptococcus pneumoniae infection in mice. Scandinavian journal immunology 2000; 52(4): 348-355.

25. Ozaslan M, Didem Karagöz I, Kalender ME, Kilic IH, Sari I, Karagöz A. In vivo antitumoral effect of Plantago 
major L. extract on BALB/C mouse with Ehrlich ascites tumor. American journal of chinese medicine 2007; 35(5): 841-851.

26. Rahamooz-Haghighi S, Asadi MH. Anti-proliferative effect of the extracts and essential oil of Pimpinella anisum on gastric cancer cells. Journal of herbmed pharmacology 2016; 5(4): 157-161.

27. Plumb JA. Cell Sensitivity Assays. In: Langdon SP eds. Cancer Cell Culture. Methods in Molecular Medicine $^{\mathrm{TM}}$. Vol 88. Humana Press. Retreived from: https://doi.org/10.1385/ 1-59259-406-9:165.

28. Aghajanzadeh $\mathrm{M}$, Zamani $\mathrm{M}$, Rashidzadeh $\mathrm{H}$, Rostamizadeh K, Sharafi A, Danafar H. Amphiphilic Y shaped miktoarm star copolymer for anticancer hydrophobic and hydrophilic drugs codelivery: Synthesis, characterization, in vitro, and in vivo biocompatibility study. Journal of biomedical materials research part a 2018; 106(11): 2817-2826.

29. Rajabi S, Ramazani A, Hamidi M, Naji T. Artemia salina as a model organism in toxicity assessment of nanoparticles. Daru 2015; 23(1): 20.

30. OECD guidelines for the testing of chemicals acute oral toxicity- up and down procedure (UDP). Reterieved from: https://www.oecd-ilibrary.org/docserver/9789264 071049-en.pdf?expires $=1611038404 \&$ id=id\&accname =guest \&checksum=4BD111B77C5C007B934ABFE2B $1 \mathrm{~B} 45663$

31. Jamilah J, Sharifa ASA, Sharifah NR. GC-MS analysis of various extracts from leaf of Plantago major used as traditional medicine. World applied sciences journal 2012; 17: 67-70.

32. Bashford JN, Norwood J, Chapman SR. Why are patients prescribed proton pump inhibitors? Retrospective analysis of link between morbidity and prescribing in the general practice research database. British medical journal 1998; 317 (7156): 452-456.

33. Ikawati Z, Wahyuono S, Maeyama K. Screening of several Indonesian medicinal plants for their inhibitory effect on histamine release from RBL-2H3 cells. Journal of ethnopharmacology 2001; 75(2-3): 249-256.

34. Yeşilada E, Sezik E, Fujita T, Tanaka S, Tabata M. Screening of some Turkish medicinal plants for their antiulcerogenic activities. Phytotherapy research 1993; 7(3): 263-265.

35. Chiang LC, Ng LT, Chiang W, Chang MY, Lin CC. Immunomodulatory activities of flavonoids, monoterpenoids, triterpenoids, iridoid glycosides and phenolic compounds of Plantago species. Planta medica 2003; 69(07): 600-604.

36. Kobeasy I, Abdel-Fatah M, El-Salam SMA, Mohamed ZEOM. Biochemical studies on Plantago major L. and Cyamopsis tetragonoloba L. International journal of biodiversity and conservation 2011; 3(3): 83-91.

37. Sutrisna E, Maskoen AM, Sujatno M, Sastramihardja HS. Potential apoptotic effect of Plantain extract (Plantago major L.) through increasing of caspase-3 level on hypergastrinemic rat model. International journal of research in pharmaceutical sciences and nanotechnology 2013; 2(3): 371-381.
38. Atta AH, Soad N, Samar M. Potential protective effect of some plant extracts against carbon tetrachlorideinduced hepatotoxicity. African journal of traditional complementary alternative medicines 2006; 3(3): 1-9.

39. Mirzaei M, Mirzaei A. Comparison of the Artemia salina and Artemia uramiana bioassays for toxicity of 4 Iranian medicinal plants. International research journal of biological sciences 2013; 2(3): 49-54.

40. Amin $\mathrm{K}$, Dannenfelser RM. In vitro hemolysis: guidance for the pharmaceutical scientist. Journal of pharmaceutical sciences 2006; 95(6): 1173-1176.

41. Femi-Adepojua AG, Adepojub AO, Durodolac FA, Abiola AGM. Phytochemical, antimicrobial and bioactive component analysis of Platycerium superbum (L.) methanolic extract. International journal of sciences: basic and applied research 2018; 40: 98-107.

42. Chen W, Vermaak I, Viljoen A. Camphor-a fumigant during the black death and a coveted fragrant wood in ancient Egypt and Babylon-a review. Molecules 2013; 18(5): 5434-5454.

43. Šála M, De Palma AM, Hřebabecký H, Nencka R, Dračínský M, Leyssen P, Neyts J, Holý A. Design, synthesis, and biological evaluation of novel coxsackievirus B3 inhibitors. Bioorganic and medicinal chemistry 2010; 18(12): 4374-4384.

44. Armaka M, Papanikolaou E, Sivropoulou A, Arsenakis M. Antiviral properties of isoborneol, a potent inhibitor of Herpes simplex virus type 1. Antiviral research 1999; 43(2): 79-92.

45. Govindappa M, Prathap S, Vinay V, Channabasava R. Chemical composition of methanol extract of endophytic fungi, Alternaria sp. of Tebebuia argentea and their antimicrobial and antioxidant activity. International journal of biological and pharmaceutical research 2014; 5(11): 861-869.

46. Kusch P, Deininger S, Specht S, Maniako R, Haubrich S, Pommerening T, Lin PKT, Hoerauf A, Kaiser A. In vitro and in vivo antimalarial activity assays of seeds from Balanites aegyptiaca: compounds of the extract show growth inhibition and activity against plasmodial aminopeptidase. Journal of parasitology research 2011; 2011: 368692 .

47. Ahmed D. Biological activities of characterized isolates of n-hexane extract of Azadirachta indica A. Juss (Neem) leaves. Nature and science 2013; 11(5): 141147.

48. Nebes RD, Pollock BG, Houck PR, Butters MA, Mulsant BH, Zmuda MD, Reynolds $3^{\text {rd }} \mathrm{CF}$. Persistence of cognitive impairment in geriatric patients following antidepressant treatment: a randomized, double-blind clinical trial with nortriptyline and paroxetine. Journal of psychiatric research 2003; 37(2): 99-108.

49. Benali T, Habbadi K, Abdelmajid K, Marmouzi I, Zengin G, Bouyahya A, Chamkhi I, Chtibi H, Tarik A, Achbani E, Hammani K. GC-MS analysis, antioxidant and antimicrobial activities of Achillea Odorata Subsp. Pectinata and ruta montana essential oils and their potential use as food preservatives. Foods 2020; 9(5): 668. 